\title{
Analysis of College English Curriculum Based on Learner's Needs
}

\author{
Xue Ni \\ Xi'an University, School of Foreign Studies, 710065
}

\begin{abstract}
Keywords: Needs of learners; Analysis; Colleges and universities; English curriculum; Setting
\end{abstract}
\begin{abstract}
With the reform of the national college education guidance and strategic objectives, the English teaching in majority of colleges and universities has been greatly improved, and teachers and leadership have recognized the significance of college English education. In the recent ten years, college English has also undergone a great degree of change; teaching mode and teaching content have been greatly improved, the curriculum goal is more generalized and the educational goal is more extensive, focusing on cultivating students' English language skills, not just the basic ability of taking examinations. However, there is still gap between the college English curriculum setting in our country and the international education mode. The teaching mode in our country still needs to be further optimized. In this paper, the problems existing in college English teaching in our country were analyzed and the corresponding solutions were proposed in order to fundamentally adjust the specific setting of Chinese college English curriculum.

College English courses are generally set up by colleges and universities and public foreign language teachers together, with undergraduate students as the teaching object. Therefore, the integration of teaching content setting, English teaching methods and assessment needs to be ensured, and English teaching should strictly follow the national English teaching policy to help colleges and universities to build a set of curriculum standards unifying class time and assessment. College English is the core of undergraduate education, and also an important discipline for undergraduate applied in the society after graduation. It can not only effectively improve the students' communication and learning ability, but also, to a large extent, lay the root for students in foreign language learning, cultivating excellent language skills. However, at present, the college English curriculum in our country lacks a fixed target, and the learning direction is too vague. Rigid teaching according to the teaching outline leads to difficulties in training students' communication ability and developing the advantages of applied discipline.

English as a common language in the world has always been the basis for the external development of China. Currently, the popularity of English education in China has been greatly improved compared to the previous few years, and the curriculum becomes more reasonable, and English language skills of students get better improvement. English is a functional discipline, thus the design of college English curriculum should be based on the student's learning situation, and English teaching content should also be fully geared to international standards. The analysis of English teaching demand is the core problem that needs to be considered in the course of setting curriculum target. The needs of students and society should be fully considered to set up the scientific, systematic and humanized English teaching courses to ensure that English teaching content can meet the need of training students' learning ability. Therefore, this paper analyzes the problems of curriculum in the process of college English teaching in colleges and universities and the needs of teaching, in order to determine the specific direction of the curriculum setting and build the training mechanism of special talents which is in line with the actual situation of university education and geared to international standards. Below the college English curriculum design in the current stage and the existing problems are simply analyzed and discussed.
\end{abstract}

\section{Analysis of the Needs of Domestic and Foreign Learners and the Foreign Language Curriculum Setting}

The model of domestic and foreign demand analysis has been developed and innovated in recent years. Researchers of Western teaching have also discussed the English teaching model in colleges and universities, and the language skill for the students' specific development after graduation. Present Situation Analysis model is created based on meeting the social needs, which uses the knowledge of the learners as the basis for analysis to develop a specific form of personalized teaching, and on this basis, Deficiency Analysis is added to ensure that personalized teaching can achieve the current college English curriculum goals. In the development process of domestic and foreign demand analysis, the most comprehensive demand model is the one created by Western scholars Dudley Evans and John. On the basis of the construction of the predemand analysis model, the learners' personal information, language information and existing problems in the learning process and such 7 aspects are added; thus the discussion of the model is more comprehensive, 
which can help the learners to construct the learning patterns associated with the curriculum, and combine the different levels of English language skills to make the demand model adapt to the goals of majority of population, so that the demand analysis can be regarded as the core basis of foreign language education policy.

Under the new situation, the training of talents in colleges and universities is mainly to prepare talents for international exchange. English learning is the key requirement for talent of international exchange, and the actual need of domestic and foreign English learners is to achieve a higher level of English ability, thus occupying a favorable position in the work. With the rapid international development of China, English has become a necessary skill for high-quality talent, and college English curriculum setting is particularly important. Colleges and universities should, by specific demand analysis, determine the actual needs of English learners of different majors, and implement personalized curriculum on this basis, so as to train the international talents that meet the social needs.

English is an international standard language, and foreign judgment on English teaching standards is significant for reference. In the process of demand analysis and curriculum setting, teachers should determine the actual English ability of students, and include the English curriculum design standards into the curriculum setting and set teaching objectives. There should be a certain degree of difference between domestic and foreign analysis on learners' demand and foreign language curriculum standards. Teaching effect of the same teaching content in different environments is different. The actual teaching should be analyzed combining with the target scenario to ensure selectivity of students in English, so as to not only meet their subjective needs in the process of English learning, but also achieve the teacher's personalized teaching strategies, setting curriculum suitable for students.

\section{The Current Situation and Main Problems of College English Curriculum}

Because of the shortcomings of college English curriculum, English learners in colleges and universities do not take classroom teaching as the main way to learn English. The boring classroom teaching cannot arouse students' initiative in English learning; most students only learn English to pass the CET-4 and CET-6 tests, and do not learn English as an instrumental discipline, especially for students of non-English majors, the English classroom learning is of little significance. The main reason for these problems is that there are different degree of defects in college English curriculum, and there is conflict between teachers' teaching methods and students' subjective consciousness in learning, which makes the college English teaching inefficient.

(1) Generalized College English Curriculum Goals and Unclear Positioning

College English reform in our country in recent years is mainly to optimize the curriculum, fundamentally change and adjust the curriculum standards. Therefore, in order to fully determine the specific direction of future English reform, college English education reform is particularly important.

At present, the college English curriculum goal in most of the colleges and universities in our country is set in accordance with the "Curriculum Requirements". However, the "Curriculum Requirements" is only a syllabus to provide guidance for English education. When the college English curriculum objectives are set fully in accordance with the "Curriculum Requirements", the English learning content will be much boring, and it is difficult for students to effectively utilize English skills in their future work. Relevant researches show that it is difficult for college English education to effectively train the comprehensive application ability of students, and students' listening and speaking ability cannot be well trained. The teaching is mainly focused on the training of reading ability and grammar. This kind of generalized teaching mode will restrict teachers' teaching ability to a great extent. Teachers as the implementers of the course can not teach with specific aims in the actual teaching process. This kind of single curriculum also makes it difficult for students to understand the significance of English teaching, forming a task-based teaching environment, in which students' learning interest and language ability cannot get better improvement.

(2) Convergence in College English Course Types and Single Content

During the reform of college English teaching, many institutions have carried out classification, and the types of courses have been changed from the traditional Integrated English into "Comprehensive Language, Language Skills, Language Applications, Language Culture and Professional English" and such compulsory courses and elective courses, or basic courses and expansion courses. Although the name or form of the courses seem to be diverse, the content is still very single in essence. For example, for course of Language Skills, teaching of comprehensive English is changed into the special training of listening, speaking, writing, reading and translating and such, and the course of Language Culture is the course for Anglo-American Profile and so on. We are far less than Hong Kong in the case of richness in curriculum content. Taking the 
"English Teaching Center" of Hong Kong Polytechnic University as an example, currently it provides up to 55 types of classes for vocation-related language training for non-English majors (excluding general English class and advanced class), such as college English for students majored in business, engineering, and design and so on. These courses combine with the majors to teach professional English communication skills, as well as how to write academic papers, participate in academic seminars, write business plans, and participate in business meetings and so on. Why the content of our college English course is so monotonous? It can be mainly attributed to three reasons: first, limitation of the resources, such as limited teacher resource resulting in difficulties in setting up so many courses; second, limitation of the English teacher's ability, and the language teachers transforming into professional English teachers need to undergo professional training; third, blindly following the patterns of pilot school without understanding the actual needs of the students and developing characteristic and popular courses; most students study English to get credits, rather than learning because of interest.

(3) The Implementation of College English Curriculum Lacks of Connotative Development, and Teaching Philosophy is Relatively Backward

At present, the college English teaching content in China is too monotonous; the teaching approach is only classroom teaching which is limited by location and practice, and the students will feel boring in the learning process, thus the teaching efficiency is greatly reduced. English teaching is a functional teaching. The actual teaching should tend to be open-ended, so that students can discuss in the relaxed and pleasant classroom atmosphere. The teachers should abandon the traditional mode of guiding-teaching, and fully inspire students' enthusiasm in the classroom through guidance, so that students can be integrated into the learning environment. In addition, the teachers should also spontaneously use English to communicate to make all-English classroom teaching normal.

(4) The Evaluation Form of College English Curriculum is Single, CET-4 and CET-6 Tests Still Prevail

A detailed evaluation system should be developed for college English teaching. Due to differences in students' learning ability and characteristics, in the process of setting curriculum, teachers should consider the situation of classroom teaching to develop a reasonable evaluation system, and use the comprehensive evaluation system to determine the teaching efficacy and the degree of students' learning at the end of the term. According to the current requirements of "Curriculum Requirements" for the evaluation system, the evaluation of college English teaching should not only focus on the summative assessment, but combine the curriculum objectives with the actual teaching situation to determine the comprehensive English skill of students, and determine whether the student has the ability to pass the assessment through the unified evaluation system. At present, most colleges and universities in China still use CET-4 and CET-6 tests as the criteria to assess students' English ability. Although the CET-4 and CET-6 tests to a large extent are able to reflect the ability of students in English, the assessment of English as an instrumental discipline should involve all aspects and we should combine with the students' speaking, reading and learning and such skills to conduct a comprehensive assessment, and link the assessment system to the actual capabilities of students to achieve the overall improvement of college English teaching model, and affect the curriculum content through the changes in assessment system.

The goal of foreign English learners is more generalized and they have a strong purposiveness. The setting of college English curriculum in our country makes the education goal not clear enough, and the learners do not have a good language atmosphere in the learning process. With the continuous improvement of demand model, learners can better determine the goal of learning, and develop language skills through other ways. College English teaching will certainly show the trend of targeted teaching, and language skills of learners will get a better improvement in this education system.

\section{Suggestions for Improvement of the College English Curriculum}

The English language courses in most of foreign countries are relatively diverse compared with China, and they increase a number of individualized teaching, effectively enhancing the initiative of students to learn English. In view of the current situation of college English curriculum in our country, the colleges and universities should establish a core curriculum setting model, enabling teachers to create a specific language training environment suitable for students' development in the process of teaching, and set the English curriculum based on the actual needs of the school.

(1) The Institutions should Plan the Characteristic Curriculum Goal based on Their Needs

During the reform of college English curriculum, the colleges and universities in our country should carry out detailed demand analysis and determine the students' English ability, as well as, on this basis, regard the "Curriculum Requirements" as the basic guidance document, and include the demand analysis into the 
curriculum standard setting to train a set of research-based, teaching-based and application-based diversified talents in accordance with the specific positioning of colleges and universities. In addition, due to the gradual diversification of planning of curriculum objectives, colleges and universities, in the process of setting up English courses, should establish multi-dimensional English course learning objectives, learning methods and learning content according to their actual needs, so as to determine the direction of content and implementation of curriculum, and build systematic curriculum standards geared to social standards.

(2) Reasonably Setting the Course Content and Properly Dealing with the Relationship between Classroom Teaching Resources and Network Media Resources

The content of the course should be set in combination with the actual teaching methods, which mainly reflects the multi-dimensional nature of learning content, reforms the traditional classroom teaching mode, and unifies the high-quality resources. Hence students can experience different teaching models in the process of learning, not only effectively improving the enthusiasm of students in study, but also greatly promoting the cultivation of language skills. In addition, in the actual teaching process, teachers should set up the relevant curriculum research group to make the curriculum contents fully meet the actual needs of society. Moreover, the institutions should vigorously promote the new media technology and network resources-based teaching methods, comprehensively utilizing the network resources and media technology to enhance the English learning atmosphere in classroom.

(3) Updating the Teaching Philosophy, Innovating Teaching Methods, and Completely Developing the Students' English Comprehensive Ability

College English courses should regard students as the main body of education, and teachers play a guiding role, achieving a dynamic innovation of the traditional teaching ideas to enable the new learning model to meet the requirements of times and society; hence the curriculum and teaching methods are changed to enhance students' self-learning ability. In addition, the traditional classroom has distinct advantages, and is essential in the teaching. Teachers in the process of reforming teaching ideas and innovating teaching methods cannot completely abandon the traditional teaching model, but should be critical to carry out curriculum reform, so that the college English learning tends to be personalized. Teachers should also encourage students to establish their own learning patterns to fundamentally improve the efficiency of English learning.

(4) Establishing a Scientific Curriculum Evaluation System and Enhancing the Promotion Role of Formative Evaluation

The standard of English curriculum will be affected by the evaluation mechanism. Therefore, the evaluation mechanism is crucial for the reform of English curriculum. Teachers should establish a humanized evaluation mechanism and effective summative assessment system to enhance student's learning efficiency. On this basis, teachers can carry out dynamic monitoring of the entire learning process. Through the understanding of students' language skills, teachers can establish feasible evaluation scheme. With the continuous reform of the content of English courses, in the course of practice, teachers should optimize the final evaluation, improve the status of the teaching assessment in the entire evaluation mechanism and develop process and developmental evaluation.

\section{Conclusion}

To sum up, the teaching of college English is a key part of the teaching system in colleges and universities, and English is the basic language discipline for students' social interaction and development after graduation. Therefore, colleges and universities should rationally implement the demand analysis, develop high quality English curriculum, dialectically view the new requirements of the times for English learning, and cultivate the comprehensive talents through the combination of different needs, thus meeting the requirements of social and economic construction and development to the largest extent, and further promoting international competitiveness of China.

\section{Reference}

[1] Liu Z.Y.,Xu Y.P. A study on the setting of police english course in public security colleges and universities - based on the analysis of social needs and learners' needs [J]. Journal of Shandong Police College,2015,2704:156-160.

[2] Shi X.Y. Exploration on the reform of college English curriculum based on the analysis of students'

learning needs [J]. Journal of Inner Mongolia Agricultural University ( Social Science

Edition),2016,1802:89-93. 
[3] Ma L.Y. Exploring the Individualized Teaching Content of College English Course in General Engineering Colleges - Based on the Needs of Learners and Social Workplace in English [J]. Journal of Jiangxi Normal University(Philosophy and Social Sciences Edition),2012,4506:141-144.

[4] Yu L.Y. A Comparative Study on the Sex of Learning Needs of Adult Learners - Based on a Survey of Learning Needs of Adult Learners [J]. Journal of China Institute of Industrial Relations,2012,2603:110113.

[5] Xia B.Y,Zeng W. An Investigation on College English Curriculum Setting Based on Student's Needs Analysis - A Case Study of Kunming Independent College [J]. College English (Academic Edition),2017,1401:40-44.

[6] Lu X.P. A Study on the Multiple Variables of Communicative Will of English Learners in Classroom Environment - A Review of "College English Learning Strategies Based on Needs Analysis" [J]. Journal of The Chinese Society of Education,2017,06:138.

[7] Hu W.F. User Needs and the Construction of Microstructure of Chinese-English Learning Dictionaries: An Empirical Study Based on Chinese EFL Learners [J]. Journal of Language and Literature,2013,2902:72-78.

[8] Wang J. Research on the Characteristics of Cadre Education Learners Based on Network Environment A Case Study of Xi'an Cadre Education and Training Radio and Television University Base Learners [J]. Modern Distance Education Research,2014,02:76-84.

[9] Tang W.Z,Li X.M. Research on the Usability of Network Excellent Course in Colleges and Universities - Based on the Experience of Users (Learners) and the Demand [J]. Journal of Distance Education,2014,3204:54-64.

[10] Wang Y,Xie Y.G. A Study on Learner's Cognitive Diagnosis Based on Pre-Concept System - A Case Study of "Power and Movement" in Junior Middle School Physics [J]. E-education Research,2017,09:1-6.

[11] Fang H.G,Luo J.P,Chen J.D,Du J.M. Research on Quantitative Self - MOOC Adaptive Learning System Based on Large Education Data [J]. E-education Research,2016,3711:38-42+92.

[12] Ren Y.X,Yu P,Yang Y. Design of Teaching Mode of QQ Group Platform Based on MOOC Teaching Idea - Taking "C Language Program Design" as an Example [J]. Journal of Yangtze Normal University,2016,3203:123-128. 